\title{
Fixing the Price Fixing Confusion: A Rule of Reason Approach
}

Despite its apparent clarity, the "per se" rule against price fixing ${ }^{1}$ has given rise to a great deal of confusion and inconsistency in antitrust law. At times, practices have been brought within the rule's scope merely because they touch upon price in some way, while at other times the economic consequences of the situation have been considered. The erratic application of the rule stems from a basic discrepancy between the legal and economic treatments of "price fixing." Analysis reveals that the courts have developed neither a clear economic definition of price fixing nor coherent criteria for applying the per se rule.

Furthermore, the per se rule has been used to strike down economically efficient behavior. ${ }^{2}$ The courts have proscribed cooperative activities on the grounds that there was some agreement as to price, even though there were potential efficiency gains similar to those available from arrangements generally evaluated under a "rule of reason" standard, such as joint ventures and partnerships. A rule of reason approach to price fixing can preserve most of the advantages of a per se rule while promoting more of the gains from efficient activities and bringing greater consistency to the law. This Note argues that the courts should therefore adopt a rule of reason approach to price fixing.

\section{Rationales for a Per Se Approach to Price Fixing}

Section 1 of the Sherman Act proscribes "[e]very contract, combination in the form of trust or otherwise, or conspiracy, in restraint of trade or commerce among the several States, or with foreign nations."3 This language was originally interpreted literally to forbid every combination in

1. "Under the Sherman Act a combination formed for the purpose and with the effect of raising, depressing, fixing, pegging, or stabilizing the price of a commodity in interstate or foreign commerce is illegal per se." United States v. Socony-Vacuum Oil Co., 310 U.S. 150, 223 (1940) (Madison Oil). As will be shown, neither a purpose to fix prices nor actual success in doing so is necessary for liability under the Madison Oil rule; rather, "[a]ny combination which tampers with price structures is engaged in an unlawful activity." Id. at 221; see infra note 42.

2. Economically efficient behavior is behavior that increases the aggregate wealth of society. This may occur either by lowering production costs (productive efficiency) or by assigning goods or services to more highly valued uses (allocative efficiency). The two forms of efficiency are closely related, since a firm that produces more efficiently will drive less efficient competitors from the market, thereby freeing the latter's resources for more highly valued uses. See F. KNIGHT, THE ECONOMIC ORGANIZA. TION 9 (1933). The terms "productive efficiency" and "allocative efficiency" are explained more fully in R. BORK, THE ANTITRUST PARADOX: A POLICY AT WAR WITH ITSELF 90-106 (1978); see also Williamson, Allocative Efficiency and the Limits of Antitrust, 59 AM. ECON. REV. PROC. 105 (1969) (proposing allocative efficiency as criterion for shaping antitrust policy).

3. 15 U.S.C. $\S 1$ (1976). 
restraint of trade, ${ }^{4}$ but this literal reading of the Act was soon qualified to recognize the validity of agreements that had no direct and immediate effect on interstate commerce ${ }^{5}$ and of restraints ancillary to agreements otherwise economically beneficial. ${ }^{6}$ This broader approach to the Sherman Act has been incorporated in a rule of reason standard often adopted when the practice in question does not involve an explicit specification of price. The Supreme Court first explicitly announced the rule of reason in Standard Oil Co. v. United States ${ }^{7}$ and elaborated the concept in Chicago Board of Trade v. United States. ${ }^{8}$ According to the rule of reason approach of Chicago Board of Trade, liability under section 1 requires not only an agreement to restrain trade but also a showing of actual or proba-

4. "When, therefore, the body of an act pronounces as illegal every contract or combination in restraint of trade. . . the plain and ordinary meaning of such language is not limited to that kind of contract alone which is an unreasonable restraint of trade, but all contracts are included in such language . . . " United States v. Trans-Missouri Freight Ass'n, 166 U.S. 290, 328 (1897) (Peckham, J.). Justice Peckham was anxious to avoid an interpretation of the Sherman Act as merely adopting the common law distinction between reasonable and unreasonable restraints of trade. The common law allowed cartels to defend themselves by arguing that the prices they charged were reasonable; Justice Peckham, however, thought it was impossible for courts to decide upon a "reasonable" price. Id. at 331 .

5. Hopkins v. United States, 171 U.S. 578, 592 (1898) (Peckham, J.) (upholding agreement to set commissions by members of livestock exchange because it had no direct effect on interstate commerce). Justice Peckham also applied the "direct and immediate effect" test in United States v. Joint Traffic Ass'n, 171 U.S. 505, 568 (1898), which struck down a railroad cartel similar to the one in United States v. Trans-Missouri Freight Ass'n, 166 U.S. 290, 328 (1897) (Peckham, J.).

6. United States v. Addyston Pipe \& Steel Co., 85 F. 271, 282 (6th Cir. 1898) (Taft, J.) ("[C]ontract must be one in which there is a main purpose, to which the covenant in restraint of trade is merely ancillary."), modified and aff', 175 U.S. 211, 244 (1899) (agreement must be upheld if its effects upon interstate commerce "were only indirect and incidental," and if "it was executed for another and entirely different purpose"). Judge Taft's decision used the common law notion of ancillary restraints to interpret the Sherman Act, 85 F. at 280-91; Justice Peckham achieved the same result by applying the "direct and immediate effect" test. 175 U.S. at 243-45.

7. "The statute. . . evidenced the intent not to restrain the right to make and enforce contracts .. . which did not unduly restrain interstate or foreign commerce, but to protect that commerce from being restrained by methods . . . which would constitute an interference, that is, an undue restraint." Standard Oil Co. v. United States, 221 U.S. 1, 60 (1911) (White, J.). Justice White's formulation of the rule of reason in United States v. American Tobacoo Co., 221 U.S. 106, 179 (1911) is also a useful one: "[T]he words 'restraint of trade' . . . only embraced acts or contracts or agreements or combinations . . . which, either because of their inherent nature or effect or because of the evident purpose of the acts, etc., injuriously restrained trade . . .."

8. 246 U.S. 231 (1918). In this case, Justice Brandeis wrote:

[T] he legality of an agreement or regulation cannot be determined by so simple a test, as whether it restrains competition. Every agreement concerning trade, every regulation of trade, restrains. To bind, to restrain, is of their very essence. The true test of legality is whether the restraint imposed is such as merely regulates and perhaps thereby promotes competition or whether it is such as may suppress or even destroy competition. To determine that question the court must ordinarily consider the facts peculiar to the business . . .; its condition before and after the restraint was imposed; the nature of the restraint and its effect, actual or probable. The history of the restraint, the evil believed to exist, the reason for adopting the particular remedy, the purpose or end sought to be attained, are all relevant facts. This is not because a good intention will save an otherwise objectionable regulation or the reverse; but because knowledge of intent may help the court to interpret facts and to predict consequences.

Id. at 238. 
ble invidious effects. ${ }^{9}$ By contrast, the adoption of a per se rule for price fixing ${ }^{10}$ was based on the Court's view that the effects of price fixing are so invariably injurious that no inquiry into them is required-merely engaging in the proscribed conduct by agreeing to fix prices is a sufficient basis for liability. ${ }^{11}$ This per se approach has been applied in other areas. Boycotts, ${ }^{12}$ horizontal market division, ${ }^{13}$ "tying" arrangements, ${ }^{14}$ and resale price maintenance ${ }^{15}$ are now subject to a per se rule. ${ }^{16}$

A per se rule can offer certain advantages. Before developing the argument for a rule of reason approach to price fixing, therefore, the Note sets out the rationales for a per se rule. Three justifications for a per se approach to price fixing have been advanced: economic reliability, ${ }^{17}$ ease of judicial administration, ${ }^{18}$ and predictability for law and business. ${ }^{10}$

9. Under that approach, intent is not by itself a basis for liability; rather, intent may be used "to interpret facts and to predict consequences." Id.

10. The complete break with the rule of reason approach was first clearly made in United States v. Socony-Vacuum Oil Co., 310 U.S. 150 (1940) (Madison Oil). See infra pp. 712-14.

11. "[T]here are certain agreements or practices which because of their pernicious effect on competition and lack of any redeeming virtue are conclusively presumed to be unreasonable and therefore illegal without elaborate inquiry as to the precise harm they have caused or the business excuse for their use." Northern Pac. Ry. v. United States, 356 U.S. 1, 5 (1958).

12. See, e.g., Klor's v. Broadway-Hale Stores, 359 U.S. 207 (1959) (group boycott of retailer by 10 national appliance manufacturers per se illegal); Fashion Originators' Guild of Am., Inc. v. FTC, 312 U.S. 457 (1941) (boycott by dress manufacturers of retailers who sold "pirated" designs per se illegal).

13. See, e.g., United States v. Topco Assocs., Inc., 405 U.S. 596 (1972) (territorial restrictions imposed in connection with joint venture to market private-label grocery products per se illegal); United States v. Sealy, Inc., 388 U.S. 350 (1967) (assignment of exclusive territories to promote joint marketing of brand-name mattresses per se illegal). But see Continental T.V., Inc. v. GTE Sylvania, Inc., 433 U.S. 36 (1977) (vertical territorial restraints to be tested under rule of reason).

14. See, e.g., Northern Pac. Ry. v. United States, 356 U.S. 1 (1958) (tying of sale of railroad's land to requirement that purchasers ship commodities produced on such land over railroad's lines per se illegal); International Salt Co. v. United States, 332 U.S. 392 (1947) (tying lease of salt processing machines to lessee's purchase of salt from manufacturer-lessor per se illegal).

15. See, e.g., United States v. Parke, Davis \& Co., 362 U.S. 29 (1960) (drug manufacturer's attempt to impose retail price of its products upon independent pharmacies per se illegal); Dr. Miles Medical Co. v. John D. Park \& Sons Co., 220 U.S. 373 (1911) (illegal for manufacturer of proprietary medicine to set prices to be charged by independent retailers where no agency relationship between manufacturer and retailer exists).

16. The per se price fixing rule has been considered the clearest and best established of the per se rules. See Rahl, Price Competition and the Price Fixing Rule-Preface and Perspective, 57 Nw. U.L. REV. 137, 137, 139 (1962) (no firmer or clearer rule of antitrust law than per se price fixing rule). If this is true, an implication of this Note's argument is that the other per se antitrust rules are even more objectionable.

17. For justification of a per se rule on the ground that it is economically reliable, see Arizona v. Maricopa County Medical Soc'y, 102 S. Ct. 2466, 2472-75, 2478 (1982); Continental T.V., Inc. v. GTE Sylvania, Inc., 433 U.S. 36, 50 n.16 (1977); Northern Pac. Ry. v. United States, 356 U.S. 1, 5 (1958); C. KAYSEN \& D. TURNER, ANTITRUST POLICY: AN ECONOMIC AND LEGAL ANALYSIS 142-43 (1959); F. SCHERER, INDUSTRIAL MARKET STRUCTURE AND ECONOMIC PERFORMANCE 509-10 (2d ed. 1980).

18. For justification of a per se rule on the grounds that it is simple to administer, see Arizona v. Maricopa County Medical Soc'y, 102 S. Ct. 2466, 2472-75, 2478 (1982); United States v. Container Corp. of Am., 393 U.S. 333, 341 (1969) (Marshall J., dissenting); C. KAYSEN \& D. TURNER, supra note 17, at 142; F. SCHERER, supra note 17 , at 510 .

19. For justification of a per se rule on the ground that it is predictable, see Arizona v. Maricopa 


\section{A. Economic Reliability}

A per se rule against price fixing is said to be appropriate because price fixing almost always has anticompetitive effects and almost never has procompetitive ones, and thus is unlikely to be of net economic benefit. "[O]nce experience with a particular kind of restraint enables the Court to predict with confidence that the rule of reason will condemn it, [the Court] has applied a conclusive presumption that the restraint is unreasonable."20 This rationale presupposes that the theory of price fixing and the evidence for it are sufficiently well developed to obviate the need for consideration of its positive effects in particular instances. ${ }^{21}$ Recognizing this, the Supreme Court has been reluctant to extend per se analysis to unfamiliar areas of business activity. ${ }^{22}$

\section{B. Ease of Judicial Administration}

If there were no administrative costs, there would be no need for per se rules: Every case could be decided on the basis of the questioned practice's effect on competition and consumer welfare. There are significant administrative costs in determining the economic effects of a course of conduct, ${ }^{23}$ however. It is generally cheaper to inquire whether the conduct has occurred than it is to investigate its effects on competition; as a result, a per se rule is likely to be less expensive to administer than a rule of reason. Courts have therefore declared certain forms of conduct to be per se illegal where an economic inquiry into such conduct is expensive and the chance that the conduct is economically beneficial is small. Thus, a per se rule against price fixing has been held to be justified if two costs-the cost of formulating the rule, and of the overinclusiveness that inevitably accompanies it-are less than the attendant savings in administrative costs. ${ }^{24}$ This

County Medical Soc'y, 102 S. Gt. 2466, 2472-75, 2478 (1982); C. KAYSEN \& D. TURNER, supra note 17, at 142; F. SCHERER, supra note 17, at 510; Rahl, supra note 16, at 149.

20. Arizona v. Maricopa County Medical Soc'y, 102 S. Ct. 2466, 2473 (1982); see Northern Pac. Ry. v. United States, 365 U.S. 1, 5 (1958).

21. See R. BORK, supra note 2 , at 36 (when economic analysis and sufficient experience from judicial inquiry show a practice can have no significant beneficial effects but is solely a means of restricting output, practice is labeled illegal per se).

22. See White Motor Co. v. United States, 372 U.S. 253, 261 (1963) (too little known about vertical territorial restraints and customer restrictions to make them per se illegal).

23. A per se rule avoids "the necessity for an incredibly complicated and prolonged economic investigation into the entire history of the industry involved, as well as related industries." Northern Pac. Ry. v. United States, 365 U.S. 1, 5 (1958).

24. Justice Marshall has stated:

Per se rules always contain a degree of arbitrariness. They are justified on the assumption that the gains from imposition of the rule will far outweigh the losses and that significant administrative advantages will result. In other words, the potential competitive harm plus the administrative costs of determining in what particular situations the practice may be harmful must far outweigh the benefits that may result. If the potential benefits in the aggregate are outweighed to this degree, then they are simply not worth identifying in individual cases. 
justification for a per se rule assumes that price fixing rarely or never promotes consumer welfare. ${ }^{2 s}$

\section{Predictability for Law and Business}

Liability under a per se rule is triggered by certain actions, not by a consideration of the purposes or effects of such actions. The court can avoid this difficult and uncertain investigation and need ask only whether the proscribed conduct has occurred. ${ }^{2 B}$ If there is a clear definition of what constitutes proscribed conduct, judicial decisionmaking can be more consistent and hence more predictable under a per se rule. Likewise, businessmen will have a clearer understanding of the legal consequences of their actions and will be able to order their affairs more effectively. ${ }^{27}$

The three rationales for the per se rule share the assumption that there is a clear definition of price fixing as an economically harmful form of conduct. ${ }^{28}$ Without such a definition, there is no basis for the claim that price fixing consistently has anticompetitive effects, and the economic rationale for the per se rule is undermined. An unpredictable price fixing standard also requires the expenditure of judicial time in determining the hazy outer boundaries of the per se rule, reducing the ease with which courts can administer this rule. Finally, an uncertain definition of price fixing cannot provide businessmen with a reliable standard by which to guide their conduct. The courts, however, have failed to develop a suitable definition of price fixing.

\section{The Origin of the Per Se Rule}

The courts' original approach to price fixing was an attempt to eliminate cartels. ${ }^{28} \mathrm{~A}$ cartel is an agreement among producers to raise their

United States v. Container Corp. of Am., 393 U.S. 333, 341 (1969) (Marshall, J., dissenting); see Ehrlich \& Posner, An Economic Analysis of Legal Rulemaking, 3 J. LEGAL STUD. 257, 262-71

(1974) (economic analysis comparing costs of administration with costs of overinclusiveness).

25. Arizona v. Maricopa County Medical Soc'y, 102 S. Ct. 2466, 2473 (1982); G. KAYSEN \& D. TURNER, supra note 17 , at 143.

26. Arizona v. Maricopa County Medical Soc'y, 102 S. Ct. 2466, 2472-73 (1982); United States v. Northern Pac. Ry., 365 U.S. 1, 5 (1958); R. BORK, supra note 2, at 36-37; C. KAYSEN \& D. TURNER, supra note 17 , at 142 .

27. Arizona v. Maricopa County Medical Soc'y, 102 S. Ct. 2466, 2473 (1982); C. KAYSEN \& D. TURNER, supra note 17 , at 142 .

28. It should be noted that this is not a requirement of a rule of reason approach, which balances procompetitive and anticompetitive effects. Indeed, a rule of reason standard explicitly recognizes that the same conduct may have anticompetitive effects in one context and procompetitive effects in another. See L. SULLIVAN, HANDBOOK OF THE LAW OF ANTITRUST 189-90 (1977). The per se rulc, in contrast, assumes that the same conduct always has more anti- than pro-competitive effects.

29. The early cases in which cartels were held to violate the Sherman Act include: United States v. Joint Traffic Ass'n, 171 U.S. 505 (1898); United States v. Trans-Missouri Freight Ass'n, 166 U.S. 290 (1897); United States v. Addyston Pipe \& Steel Co., 85 F. 271 (6th Cir. 1898), modified and aff'd, 175 U.S. 211 (1899). Robert Bork has argued that cartels were one of three basic phenomena 
prices above the competitive level by lowering production. ${ }^{30}$ Such an agreement, which can be effective only if the cartel members possess market power, ${ }^{31}$ results in a transfer of wealth from consumers to producers, and a loss of allocative efficiency due to the lower volume of production. ${ }^{32}$ It is this latter result-a decrease in the overall wealth of society as a whole-that provides the economic rationale for proscribing cartels. ${ }^{33}$ The rule against cartels exhibited clarity, consistency, and economic sense; the price fixing rule that it spawned lacked all three of these qualities. By proscribing any conduct that "affects price," courts can strike down conduct without regard to its economic consequences.

\section{A. From Cartels to Price Fixing}

The earliest cases enforcing the Sherman Act declared cartels illegal under section $1 .^{34}$ Agreements among producers with market power ${ }^{35}$ to raise prices or lower output were known to have socially undesirable economic effects. Once such an agreement was established, therefore, there

(along with monopolistic mergers and predatory business tactics) that Congress sought to prevent in passing the Sherman Act. Bork, Legislative Intent and the Policy of the Sherman Act, 9 J.L. \& ECON. 7,11 (1966). For a general view of the early history and interpretation of the Sherman Act, see W. LETWIN, LAW AND ECONOMIC POLICY IN AMERICA (1965).

30. See J. Hirshleifer, PRICE THeORY AND APPLications 357 (2d ed. 1980). Under pure competition, the price charged by a firm will equal its marginal cost-the cost of producing its last unit of output. Id. at 288. By agreeing to restrict output, members of a cartel seek to create an artificial scarcity for their good so that they are able to charge consumers a higher price. Id. at 357.

31. An effective cartel is a group of producers acting in concert as a monopoly, so that its members collectively have the market power of a monopoly. Id. at 340-41. Producers have market power if they collectively face a downward-sloping demand curve, so that their joint output decisions will determine what price they can charge. Id.; see also Landes \& Posner, Market Power in Antitrust Cases, 94 HARV. L. REV. 937, 937 (1981) (group of firms acting jointly has market power if it is able to raise price above marginal cost without losing so many sales so quickly that it must rescind price increase).

32. See J. HIRSHLEIFER, supra note 30 , at 344-46. One commentator also maintains that the possibility of gaining monopoly returns will cause a further social loss as producers expend valuable resources in their efforts to obtain a socially undesirable monopoly. See R. POSNER, ANTITRUST LAW: AN ECONOMIC PERSPECTIVE 39 (1976). Cartels may conceivably produce efficiency gains, but the possibility of such gains is extremely remote. See infra note 147.

33. This was recognized by Justice Peckham in the first case enforcing the Sherman Act. See United States v. Trans-Missouri Freight Ass'n, 166 U.S. 290, 323-24 (1897) (combinations whose purpose is to control market for particular product may cause harm by raising price at whim). Richard Posner has called the elimination of formal cartels from industries subject to the Sherman Act "the major achievement of American antitrust law." R. POSNER, supra note 32, at 39.

34. See supra note 29.

35. It is reasonable to conclude that the defendants in the early cases had considerable market power in a defined geographic market. In Trans-Missouri, the defendants controlled all rail freight traffic between the Pacific Ocean and the Mississippi River. United States v. Trans-Missouri Freight Ass'n, 166 U.S. 290, 298 (1897). In Joint Traffic, the defendants comprised "most (but not all) of the lines engaged in the business of railroad transportation between Chicago and the Atlantic coast." United States v. Joint Traffic Ass'n, 171 U.S. 505, 506 (1898). In Addyston Pipe \& Steel, the defendants controlled two-thirds of the production of cast iron pipe in a market comprising over threequarters of the territory of the United States. United States v. Addyston Pipe \& Steel Co., 85 F. 271, 291-92 (6th Cir. 1898), modified and aff'd, 175 U.S. 211 (1899). 
was no need for a detailed factual investigation of its actual effects. ${ }^{38}$ The courts refused to hear arguments that prices set by a cartel were "reasonable"s7 or that a cartel might be necessary to prevent "ruinous competition."ss

The Supreme Court expanded the set of price agreements subject to an irrebuttable presumption of illegality from cartels to price fixing in the Madison Oil case, ${ }^{38}$ in which it inferred the existence of a cartel from an agreement among the major oil companies to buy up surplus oil that had been flooding the spot market and depressing prices. ${ }^{40}$ The Court's decision was innovative in three ways. First, the Court inferred the presence of a cartel from the agreement to buy surplus oil rather than from actual direct regulation of price. ${ }^{11}$ Second, it stated that whether the parties to a price fixing agreement could or did succeed in fixing prices was irrelevant. ${ }^{42}$ Third, the Court characterized the invidious conduct as price

36. Trans-Missouri, Joint Traffic, and Addyston Pipe \& Steel were all decided against the defendants without trial.

37. United States v. Trans-Missouri Freight Ass'n, 166 U.S. 290, $331-32$ (1897); United States v. Addyston Pipe \& Steel Co., 85 F. 271, 293 (6th Cir. 1898), modified and affd, 175 U.S. 211 (1899).

38. United States v. Trans-Missouri Freight Ass'n, 166 U.S. 290, 330-32 (1897). In United States v. Trenton Potteries Co., 273 U.S. 392 (1927), the Court upheld a ruling that once cartel behavior had been established it was unnecessary to consider the reasonableness of the prices that were fixed or the good intentions of the cartel members. Id at 395. It should be noted that while the Court speaks of price fixing agreements as "in themselves . . . unlawful," id. at 397, the defendants controlled $82 \%$ of the market for vitreous pottery, and the holding was limited to "[a]greements which create such potential power." Id. This consideration of effects makes the holding in Trenton Potteries less than a true per se rule. Furthermore, the Court based its holding on the lower court's finding that the defendants had formed a cartel. Id. at 394. Trenton Potteries-like Trans-Missouri, Joint Traffic, and Addyston Pipe \& Steel-may therefore be said to stand for a per se rule against cartels, but not against "price fixing" simpliciter. See Note, The Per Se Illegality of Price-Fixing-Sans Power, Purpose, or Effect, 19 U. CHI. L. REV. 837, 855 (1952) (Trenton Potteries precedent only for proposition that price fixing among parties with market power unreasonable per se).

39. United States v. Socony-Vacuum Oil Co., 310 U.S. 150 (1940).

40. Id. at $190-91$.

41. Id. One of the results of the rule of Madison Oil has thus been to transform the law of price restraints into a law of conspiracy. Since the courts may abstract from any consideration of effects in applying the per se rule, the focus of attention becomes whether the defendants agreed on a course of conduct concerning prices. In addressing the issue of agreement, courts have applied the traditional apparatus of the law of conspiracy. See R. POSNER, supra note 32, at 24-25. Since mere agreement to engage in the proscribed conduct is sufficient to impose liability, a further consequence of the conspiracy approach is a focus on inchoate violations-the attempt to fix prices rather than actual success in doing so. Id. at 40-41.

42. The Court in Madison Oil stated that proof of price rises in the Mid-West resulting from the oil companies' buying program was essential to establish jurisdiction in the Western District of Wisconsin, 310 U.S. at 224 n.59, but it added that such proof

does not mean that both a purpose and a power to fix prices are necessary for the establishment of a conspiracy under $\S 1$ of the Sherman Act. . . [I]t is well established that a person "may be guilty of conspiring although incapable of committing the objective offense." . . It is the "contract, combination . . . or conspiracy in restraint of trade or commerce" which $\S 1$ of the Act strikes down, whether the concerted activity be wholly nascent or abortive on the one hand, or successful on the other.

Id. Although footnote 59 is dicta in light of the Court's holding, it has had great influence and has been frequently cited by both the Supreme Court and lower courts as an authoritative statement of the per se price fixing rule. See, e.g., Arizona v. Maricopa County Medical Soc'y, 102 S. Ct. 2466, 2477 
fixing but offered no definition of this proscribed behavior, asserting only that "[a]ny combination which tampers with price structures is engaged in an unlawful activity."4s

Madison Oil dramatically shifted the focus of the courts' approach to violations of section $1 .^{44}$ In the early cases, the courts in effect declared cartel behavior to be per se illegal and refused to inquire into the reasonableness of prices or possible offsetting noneconomic benefits ${ }^{45}$ provided by cartels. The refusal to consider offsetting effects presupposes the existence of a cartel with market power, with its necessarily harmful economic consequences. Madison Oil, however, focuses on price fixing rather than car-

n.23 (1982); United States v. Container Corp. of Am., 393 U.S. 333, 337 (1969); Hanover Shoe, Inc. v. United Shoe Mach. Corp., 392 U.S. 481, 497 n.12 (1968); White Motor Co. v. United States, 372 U.S. 253, 265 n.2 (1963) (Brennan, J., concurring); Berkey Photo, Inc. v. Eastman Kodak Co., 603 F.2d 263, 272 (2d Cir. 1979), cert. denied, 444 U.S. 1093 (1980); United States v. Gasoline Retailers Ass'n, 285 F.2d 688, 691 (7th Cir. 1961); Independent Taxicab Operators' Ass'n v. Yellow Cab Co., 278 F. Supp. 979, 983 (N.D. Cal. 1968); United States v. United States Steel Corp., 233 F. Supp. 148, 151 n.3 (S.D.N.Y. 1964); United States v. Central States Theatre Corp., 187 F. Supp. 114, 145 (D. Neb. 1960).

Not even an intent to engage in harmful conduct is a requirement for liability under the Madison Oil per se rule. 310 U.S. at 221-22; see Kiefer-Stewart Co. v. Joseph E. Seagram \& Sons, Inc., 340 U.S. 211 (1951) (maximum price fixing by manufacturer per se illegal even though manufacturer's purpose was to prevent distributor from reaping monopoly profits). Thus, while neither intent to bring about competitive harm nor actual success in producing anticompetitive effects is necessary for liability under the per se rule, either condition by itself may be sufficient. In Kiefer-Stewart the court imposed liablility for maximum price fixing even though there was a procompetitive purpose and the defendants lacked the monopoly power necessary to affect the market price. The only issue was whether the defendants had agreed to set the maximum prices. See Note, supra note 38, at 862-64 (Kiefer-Stewart precedent for proposition that price fixing literally illegal per se, without regard to power, purpose, or effect); cf. Morris, Is Price-Fixing Per Se Reasonable? A Discussion, 47 KY. L.J. 63, 79 (1958) (courts have no principled basis for distinguishing between power or economic effect approach to price fixing and purpose or intent approach).

43. Madison Oil, 310 U.S. at 221. The difficulty with this notion of price fixing is that, stripped of any consideration of market power or competitive effects, it lacks any economic content. See infra pp. 714-15. Cases which have applied the per se rule in a literal sense include Arizona v. Maricopa County Medical Soc'y, 102 S. Ct. 2466 (1982) (maximum fee schedule set by physicians as part of full-coverage health insurance plan per se illegal); Catalano v. Target Sales, Inc., 446 U.S. 643 (1980) (per curiam) (agreement among beer distributors to eliminate short-term trade credit to retailers per se illegal); Kiefer-Stewart Co. v. Joseph E. Seagram \& Sons, Inc., 340 U.S. 211 (1951) (maximum resale prices set by distillers to counter distributor's monopoly pricing per se illegal); In re Plywood Antitrust Litig., 655 F.2d 627 (5th Cir. 1981) (agreement to maintain a delivered pricing system per se illegal, even though total delivered prices varied among producers), cert. dismissed sub noms. Weyerhaeuser Co. v. Lyman Lamb Co. and Georgia-Pacific Corp. v. Lyman Lamb Co., 103 S. Ct. 3100 (1983); Plymouth Dealers' Ass'n v. United States, 279 F.2d 128 (9th Cir. 1960) (agreement by automobile dealers to adopt a schedule of "list prices" per se illegal, even though prices only used as a starting point for bargaining with individual customers).

44. See R. POSNER, supra note 32, at 25 (after Madison Oil, rule against price fixing became part of law of conspiracy instead of law of monopoly); cf. Easterbrook, Maximum Price Fixing, 48 U. CHI. L. REV. 886, 908-09 (1981) (holding in Madison Oil that law allows no inquiry into economic justification for cooperation among rivals reversed longstanding approach to per se doctrine).

45. But see Chicago Bd. of Trade v. United States, 246 U.S. 231 (1918) (beneficial effects of shortened work day relevant to determining legality of grain exchange's restriction of hours during which its members may trade). This case was a departure from the Court's customary procedure of considering only competitive effects of possible price restraints. Even in Chicago Board of Trade, however, the primary rationale for the Court's decision upholding the exchange's restriction of trading hours was the improved market it created. Id. at 240-41. 
tels; as a result, courts can proscribe activities even though no invidious purpose or harmful economic consequences have been established, and even though the economic results of the conduct may be of net benefit to consumers. In practice, this expansion of liability for price fixing has allowed a great deal of arbitrariness in the decisionmaking process. Literal application of the per se rule would strike down virtually all commercial agreements, but it is clear that not all agreements that somehow affect price are per se illegal. ${ }^{46}$ Unfortunately, the per se approach provides no basis for distinguishing exceptions. Economic considerations are frequently downplayed in favor of the conclusory label of price fixing. ${ }^{47}$ Under the per se approach, the principal issue in price fixing cases is often the characterization of the agreement in question. A characterization that ignores market power and economic effects, however, is bound to be arbitrary.

\section{B. Lack of an Economic Theory of "Price Fixing"}

Effective application of a per se rule against price fixing presupposes a well-established theory of price fixing as an economically indefensible activity. ${ }^{48}$ The concept of price fixing announced in Madison Oil, however, imposes liability for conduct apart from any consideration of the conduct's economic effects-it is a legal rather than an economic category. Not every "agreement concerning price" is economically invidious (as witnessed by the well-recognized exceptions to the per se rule $\left.{ }^{49}\right)$, but rather agreements by producers with market power to restrict output and raise prices above competitive levels. ${ }^{50}$ The per se rule against price fixing thus undermines competition and consumer welfare. In addition, without a clear basis in economic theory for determining what price fixing is, the rationales supporting the use of a per se rule are far less persuasive.

Thus, there is an unresolved tension between the legal approach to

46. Virtually all commercial transactions, from the simplest sales contract to more complex arrangements such as partnership agreements and joint ventures, "fix" price in some way. The recognized validity of such commercial arrangements-indeed, their indispensability for the functioning of a market economy - requires many exceptions to a literal per se rule. See id. at 238 (every commercial agreement restrains trade; true test of legality of a restraint must be whether it suppresses or destroys competition); $c f$. United States v. Addyston Pipe \& Steel Co., 85 F. 271, 281 (6th Cir. 1898) (restraints of trade valid at common law if reasonably necessary to protect interests of buyer of property, to advance legitimate ends of a partnership, or to protect employer's business from unjust use of confidential information by former employee), modified and aff'd, 175 U.S. 211 (1899). These restraints have continued to be upheld under the Sherman Act. See United States v. Timken Roller Bearing Co., 83 F. Supp. 284, 312 (N.D. Ohio 1949) (joint venture or partnership formed for purpose of promoting legitimate business enterprise lawful under Sherman Act), modified and afTd, 341 U.S. 593 (1951).

47. See infra pp. 717-20.

48. See supra p. 709.

49. See supra note 46.

50. See supra pp. 710-11. 


\section{Price Fixing}

price fixing under the per se rule and the economic basis for its prohibition. Since there is no economic theory of harm from price fixing apart from the harms from anticompetitive cartels, it is impossible to discern price fixing in other than a merely literal sense without examining the purpose and effects of the questioned behavior and the market structure within which it has occurred. As a result, the distinction between characterizing a practice as price fixing and determining its purpose and effect, and hence the distinction between the per se rule and a rule of reason, cannot ultimately be maintained. ${ }^{51}$ In practice, the per se rule must either become identical with the rule of reason or give rise to an arbitrary and conclusory labeling of agreements that happen to concern price in some respect.

\section{Invidious Consequences of the Per Se Rule}

The lack of clarity about what constitutes "price fixing" and the inadequate guidance provided by the standard of Madison Oil are reflected in the kinds of legal arguments used to assign liability under the per se rule.

\section{A. Divergence of Legal Theories from Economic Harm}

Because price fixing as a legal category has no coherent economic rationale, it allows courts to develop legal theories of liability that have little connection with economic harm. This lack of congruence may be seen from a review of the various inferences that can be used to support a holding of price fixing.

Three broad types of per se price fixing theories may be distinguished: (i) cases involving explicit cartel agreements, ${ }^{52}$ (ii) cases in which cartel behavior is inferred from agreements or other behavior not directly concerned with prices, ${ }^{\text {ss }}$ and (iii) cases involving some aspect of price where

51. But see $\mathrm{R}$. BORK, supra note 2, at 263-79 (arguing that necessary exceptions to per se rule do not detract from its merit since they can be given a principled basis by means of the distinction between primary and ancillary restraints). For a discussion of Bork's views, see infra pp. 727-28.

52. See, e.g., United States v. Trans-Missouri Freight Ass'n, 166 U.S. 290 (1897) (rate fixing by railroad cartel that controlled all rail traffic between the Mississippi and Pacific, including written articles of agreement providing for voting and enforcement procedures); United States v. Addyston Pipe \& Steel Co., 85 F. 271 (6th Cir. 1898) (cartel of steel pipe manufacturers, which controlled twothirds of the production of steel pipe in a market comprising three-quarters of the territory of the United States, set prices and organized bid rigging on contracts), modified and affd, 175 U.S. 211 (1899); United States v. Trenton Potteries, 273 U.S.. 392 (1927) (cartel of bathroom fixture manufacturers, which controlled $82 \%$ of market for vitreous pottery, set prices and restricted output); Virginia Excelsior Mills v. FTC, 256 F.2d 538 (4th Cir. 1958) (exclusive sales agent set prices for independent excelsior producers who accounted for $25 \%$ of East Coast production); United States v. American Smelting \& Ref. Co., 182 F. Supp. 834 (S.D.N.Y. 1960) (joint selling agreement between two largest lead miners in U.S.).

53. Sec, e.g., United States v. Socony-Vacuum Oil Co., 310 U.S. 150 (1940) (Madison Oil) (cartel of oil producers inferred from agreement to buy up surplus oil on spot market); National Maca- 
the court develops no cartel theory or other explanation of how the behavior in question is anticompetitive. This third class may, in turn, be divided into two subclasses: cases in which the agreement regarding price is explicit, $^{54}$ and those in which the court infers an agreement from parallel conduct or communications. ${ }^{\mathrm{s5}}$ While a per se rule may be appropriate for the first class of cases, ${ }^{\mathrm{b} B}$ it is inappropriate for the other two.

\section{Inferred Price Fixing}

Where cartel behavior is inferred from behavior not directly concerning price, the court should have a theory of how the activity in question will result in higher prices or reduced output. In one ostensibly per se case, ${ }^{37}$ the court peeked at the economic merits and propounded such a theory, inferring price fixing on the part of buyers from an agreement to set quality standards. ${ }^{58}$ The court ostensibly applied the per se rule but nonetheless recognized that the buyers were exercising market power in their purchases of a production input. ${ }^{89}$ In Madison Oil itself, ${ }^{80}$ on the other hand, the Supreme Court presumed that the program of buying surplus oil on the spot market raised prices in the forward contract market. ${ }^{61}$ It is unclear, however, how the buying program could have had any effect on the long-run supply of oil available in the forward contract market. ${ }^{62}$ Since the storage facilities of the major producers were finite, the oil they purchased on the spot market would eventually find its way into the forward contract market, thereby depressing prices. The mere agreement to

roni Mfrs. Ass'n v. FTC, 65 F.T.C. 583 (1964) (buyers' cartel of macaroni manufacturers inferred from agreement to reduce percentage of durum wheat used in macaroni products), aff'd, 345 F.2d 421 (7th Cir. 1965).

54. See, e.g., Arizona v. Maricopa County Medical Soc'y, 102 S. Ct. 2466 (1982) (maximum fees set by physicians); Kiefer-Stewart Co. v. Joseph E. Seagram \& Sons, Inc., 340 U.S. 211 (1951) (maximum price fixing by distiller); Plymouth Dealers' Ass'n v. United States, 279 F.2d 128 (9th Cir. 1960) (circulation of price list by automobile dealers).

55. See, e.g., Catalano, Inc. v. Target Sales, Inc., 446 U.S. 643 (1980) (per curiam) (alleged agreement among beer distributors to eliminate short-term credit to retailers); In re Plywood Antitrust Litig., 655 F.2d 627 (5th Cir. 1981) (agreement to fix plywood prices inferred from manufacturers' use of common delivered price system), cert. dismissed sub noms. Weyerhaeuser Co. v. Lyman Lamb Co. and Georgia-Pacific Corp. v. Lyman Lamb Co., 103 S. Ct. 3100 (1983).

56. At least one commentator believes that even explicit cartel agreements can sometimes promote efficiency. See R. BORK, supra note 2, at 435-39.

57. National Macaroni Mfrs. Ass'n v. FTC, 345 F.2d 421 (7th Cir. 1965).

58. The manufacturers of macaroni agreed to reduce its semolina content in response to a shortage of durum wheat, from which semolina is made. Id. at 424.

59. The macaroni industry was the only market for durum wheat. National Macaroni Mfrs. Ass'n v. FTC, 65 F.T.C. 583, 611 (1974), aff', 345 F.2d 421 (7th Gir. 1965).

60. United States v. Socony-Vaccum Oil Co., 310 U.S. 150 (1940) (Madison Oil).

61. Id. at 190-91.

62. This does not mean that the major producers did not engage in some sort of anticompetitive activity; the Court's analysis, however, failed to show how they did so. 


\section{Price Fixing}

buy up oil on the spot market, without more, could not have had the effect that the Court attributed to it.

\section{Behavior Affecting Price}

If the questioned behavior merely concerns or affects price in some way, the court should require a showing that this behavior is anticompetitive before striking it down. Where an agreement to set a single element of price (but not the total price) is inferred on the basis of circumstantial evidence, the per se approach becomes especially arbitrary. In a recent

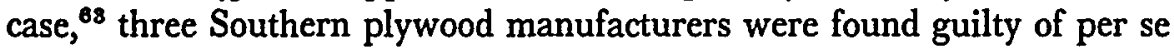
violations of section 1 of the Sherman Act for conspiring to maintain a uniform system of "delivered" pricing. ${ }^{64}$ In accordance with the per se approach, no adverse effect on total prices was found or even considered. ${ }^{.5}$

Plywood was originally manufactured exclusively from Western fir in the Pacific Northwest and shipped to all parts of the country from this region. ${ }^{\text {s }}$ Prices were quoted as a mill price plus rail freight delivery charges from the West Coast. ${ }^{67}$ When the Southern mills entered the mar$\mathrm{ket}^{\mathrm{es}}$ they too quoted a mill or index price plus delivery charges, but the Southern quotes included delivery charges from the West Coast, even though the actual delivery costs to buyers in the South and East were

63. In re Plywood Antitrust Litig., 655 F.2d 627 (5th Gir. 1981), cert. dismissed sub noms. Weyerhaeuser Co. v. Lyman Lamb Co. and Georgia-Pacific Corp. v. Lyman Lamb Co., 103 S.Ct. 3100 (1983). The Plywood case was settled for $\$ 165$ million. Potential liability was estimated at $\$ 2$ billion. Wall St. J., Dec. 15, 1982, at 3, col. 1. In an appeal from a case brought by the FTC under section 5 of the Federal Trade Commission Act and tried on the same facts as Plywood, the Ninth Circuit reached a conclusion contrary to that of the Fifth Circuit. Boise Cascade Corp. v. FTC, 637 F.2d 573 (9th Cir. 1980) (no liability for alleged agreement to adopt delivered price system since defendant's conduct was consistent with competitive behavior).

64. In re Plywood Antitrust Litig., 655 F.2d at 633.

65. The issue that the court addressed in finding a violation of section 1 was whether the defendants had conspired to use the delivered pricing system. Id. at 632 . The court also considered the defendants' use of "standard weights," a common practice in the plywood industry arising from the need to quote a firm price before the actual weight (which depends in part on the type of wood used in the manufacturing process) is known. In re Boise Cascade Corp., 91 F.T.C. 1, 30-31 (1978), rev'd, 637 F.2d 573 (9th Gir. 1980). The standardized weights were contained in the 1934 National Recovery Act Code of Fair Competition and subsequently published by the Office of War Information in 1943 and by the Office of Price Stabilization in 1952. Id. at $31 \mathrm{n} .43$. Since the use of standard weights presents issues analogous to those raised by the West Coast freight pricing scheme, and since the use of that scheme would have been a sufficient basis for a section 1 violation under the Fifth Circuit's holding, the discussion here is limited to the West Coast freight issue.

66. Boise Cascade Corp. v. FTC, 637 F.2d 573, 573-74 (9th Cir. 1980).

67. Id. at 574. Freight charges from the West Coast were computed on the basis of concentric zones radiating eastward from Portland, Oregon. Charges were identical within any single zone. Id.

68. In 1963, Georgia Pacific, one of the defendants, achieved a technological breakthrough that enabled it to make plywood from Southern pine. See In re Boise Cascade Corp., 91 F.T.C. 1, 12 (1978), rev'd, 637 F.2d 573 (9th Cir. 1980). It opened the first plywood mill in the South in 1964. Id. Other companies quickly followed this lead, and by 1971 there were 51 Southern plywood mills in operation. Id. at 3 . 
lower than they would have been from the West Coast. ${ }^{69}$ The Southern index prices were not actual "free on board" (f.o.b.) mill prices; ${ }^{70}$ instead, they were adjusted to offset the West Coast delivery charges. ${ }^{71}$ Index prices at the Southern mills varied among producers ${ }^{72}$ and fluctuated widely over time. ${ }^{73}$

It is unlikely that an agreement to maintain a method of price quotation, in the absence of any showing that total price was affected, has an anticompetitive effect. ${ }^{74}$ Indeed, the seemingly peculiar method for quoting prices of the Southern manufacturers has a clear procompetitive justification. It reduces information costs to consumers comparing Western and Southern plywood ${ }^{75}$ by enabling them to compare the respective mill prices directly and to determine the total delivered price simply by adding the same standard freight charge to each mill quotation. ${ }^{78}$ With plywood prices changing daily and even hourly and with buyers requesting quotations from Southern and Western producers by telephone, ${ }^{77}$ the ability to make quick comparisons among simple index prices was a significant ad-

69. Boise Cascade Corp. v. FTC, 637 F.2d 573, 574 (9th Gir. 1980).

70. Id. at 578 .

71. Id. at 580 .

72. Id. at 579.

73. 46 Record on Appeal at 525-26; 54 Record on Appeal at 2753, 2770-71, In re Plywood Antitrust Litig., 655 F.2d 627 (5th Cir. 1981), cert. dismissed sub noms. Weyerhaeuser Co. v. Lyman Lamb Co. and Georgia-Pacific Corp. v. Lyman Lamb Co., 103 S. Ct. 3100 (1983).

74. Commentators differ on the rationale and effects of a basing-point pricing system. Compare Stigler, A Theory of Delivered Price Systems, 39 AM. ECON. REv. 1143 (1949), reprinted in G. STIGLER, THE ORGANIZATION OF INDUSTRY 147 (1968) (basing-point price system facilitates cartelization by more evenly distributing sales among cartel members in geographically dispersed markets characterized by wide fluctuations in demand) with Haddock, Basing-Point Pricing: Competitive vs. Collusive Theories, 72 AM. ECON. REV. 289, 290 (1982) (competitive participants in spatially dispersed market "have no reasonable alternative" to basing-point system). The fact that Southern index prices differed both from one another and from West Coast mill prices distinguishes Plywood from earlier cases in which liability was imposed for concerted adoption of a basing-point system. See, c.g., FTC v. Cement Inst., 333 U.S. 683 (1948) (concerted adoption of a multiple basing-point system and persistent identity of base prices); Sugar Inst. v. United States, 297 U.S. 553 (1936) (concerted maintenance of basing-point system including agreement to adhere to published prices); Allied Paper Mills v. FTC, 168 F.2d 600 (7th Cir. 1948) (overt agreement regarding all aspects of price, including uniform base prices), cert. denied, 336 U.S. 918 (1949); cf. Boise Cascade Corp., 91 F.T.C. 1, 70 (1978) (no showing that West Coast freight system operated in manner of classic basing-point system and no showing that southern plywood industry follows an absolutely uniform base price to which West Coast freight is added), rev'd on other grounds, 637 F.2d 573 (9th Cir. 1980).

75. Because buyers were accustomed to the West Coast freight quotation method, this ease of price comparison helped the Southern mills enter the market. It remained important after entry since buyers in some parts of the country continued to purchase both Southern and Western plywood.

76. The reduction of information costs aids competition. See F. SCHERER, supra note 17, at 11 (perfect knowledge of present and future market conditions prerequisite for pure competition); $R$. POSNER, supra note 32, at 136 (since information is costly to acquire, customers may lack good information about competitive alternatives facing them); L. SULLIVAN, supra note 23, at 268 (rapid dissemination of price information prerequisite for competitive market).

77. 45 Record on Appeal at 299; 48 Record on Appeal at 1035, 1071, 1075, In re Plywood Antitrust Litig., 655 F.2d 627 (5th Cir. 1981), cert. dismissed sub noms. Weyerhaeuser Co. v. Lyman Lamb Co. and Georgia-Pacific Corp. v. Lyman Lamb Co., 103 S. Ct. 3100 (1983). 
vantage. ${ }^{78}$ The result was increased competition among all plywood producers and reduced search costs for plywood consumers. ${ }^{70}$

Assuming that the Southern plywood manufacturers had agreed to maintain the West Coast freight price quotation method, they may be said to have engaged in "price fixing" in a literal sense: Their concerted action had some effect on price, namely, on the method of price quotation. However, the connection between the per se rule against price fixing and the economic justification for the early rule proscribing cartels is extremely tenuous in the Plywood case. The rationale on which liability was predicated is twice removed from proof of cartelization: First, the proscribed actions merely concerned price, but prompted no consideration by the court of anticompetitive effects; second, an agreement to use the West Coast price quotation scheme was inferred from parallel behavior and business contacts. ${ }^{80}$ Where the relation of proscribed behavior to anticompetitive harm is so remote, it is clear that the courts have gone far beyond the rationale for the rule against cartels laid down in the early cases. ${ }^{81}$

If liability can be based on any concerted conduct that affects price in any way, the plaintiff will try to prove agreement or conspiracy, ${ }^{\mathbf{8 2}}$ since this will probably be easier than showing an anticompetitive effect. ${ }^{83} \mathrm{Be}-$ cause of the wide latitude available to triers of fact in applying standards

78. This was especially true since Southem freight rates were calculated on a point-to-point basis and varied according to the weight of the load. Boise Cascade Corp. v. FTC, 637 F.2d 573, 574 n.1 (9th Cir. 1980). This would make it difficult for buyers to make rapid price comparisons if actual mill prices were quoted.

79. By facilitating price comparisons among sellers, the West Coast pricing scheme may also have narrowed the dispersion of prices, thereby increasing allocative efficiency. See R. POSNER, supra note 32, at 135-47 (the more information sellers have about prices of competitors, the more efficient the market); Posner, Information and Antitrust: Refiections on the Gypsum and Engineers Decisions, 67 GEO. L.J. 1187, 1188 (1979) (exchange of price information reduces incidence of prices that reflect ignorance of buyers and sellers about conditions of supply and demand). It is true, however, that this rationale would have provided an incentive for agreement to adopt the West Coast freight pricing system. In the absence of any agreement to fix total delivered prices, however, such an agreement may have had procompetitive effects.

80. In Ethyl Corp., 3 TRADE REG. REP. (CCH) I 22,003 (F.T.C. Mar. 22, 1983), the FTC found that certain "facilitating practices" by the manufacturers of lead antiknock compounds-which included advance notice of price changes, "most-favored-nation" price clauses in sales contracts and a uniform delivered price system-constituted an unfair method of competition in violation of section 5 of the Federal Trade Commission Act, even though such practices were adopted independently. Contrary to the Fifth Circuit's approach in Plywood, however, the Commission applied a rule of reason standard, id. at 22,526, and emphasized the importance of a detailed economic analysis of the structure of the industry and the effects of the practices in question, id. at 22,531.

81. See supra pp. $710-11$.

82. See R. POSNER \& F. EASTERbroOK, ANTITrust: Cases, Economic Notes and OTHER MATERIALS 306-08 (2d ed. 1981).

83. Thus, the court in Plywood ignored the issue of whether or how the West Coast freight pricing system produced anticompetitive effects and merely addressed the question of whether there was an agreement to adopt that system. See id. at 307-08; see also Priest, Cartels and Patent Licenses, 20 J.L. \& ECON. 309, 312 (1977) (many declarations of managers ambiguous and consistent with either collusive or competitive intent). 
of proof in conspiracy cases ${ }^{84}$ and the unpredictable effects of circumstantial evidence on juries unacquainted with normal industry practices, ${ }^{\mathbf{8 5}}$ the per se rule has been a source of unpredictability in the calculations of both businessmen and lawyers, ${ }^{86}$ contrary to one of its purported rationales. ${ }^{87}$ Furthermore, the expensive discovery associated with conspiracy cases ${ }^{88}$ offsets some of the savings in administrative costs that traditionally have been attributed to the per se rule. ${ }^{80}$

A true per se rule ignores economic power or effects in determining liability. The analysis so far has focused on the discrepancy between the economic effects of actions and the legal inferences by which they may be held to be price fixing. The invidious consequences of this discrepancy are only exacerbated when a per se rule is tacitly supplernented by a rule of reason approach.

\section{B. Erratic Application}

With respect to agreements that concern price in some way but do not fall within the well-established exceptions, ${ }^{90}$ three outcomes are possible: (i) the agreement may be struck down as per se illegal;91 (ii) the agreement may be struck down under a rule of reason approach; ${ }^{92}$ or (iii) the agreement may be upheld as legal. ${ }^{93}$

There is no principled basis for determining which of these approaches will be used by the courts. For example, in the $A S C A P$ case, ${ }^{94}$ the owners

84. The Plywood cases are a good example of this. On the same set of facts, the Fifth Circuit found sufficient proof of agreement but the Ninth Circuit did not. See supra note 63.

85. See F. SCHERER, supra note 17 , at 510-11.

86. Cf. Bloom, A Guide to Antitrust, 20 Bus. LAW. 61, 61-62 (1964) (individual noncooperative action key to legality in all business relations, yet "such conduct is impossible").

87. See supra p. 710.

88. See R. POSNER \& F. EASTERBROOK, supra note 82 , at 595-98 (discovery of millions of documents routine).

89. Cf. id. at 597 (uncertain rule increases number of cases that must be litigated and reduces likelihood of settlement).

90. See supra note 46 .

91. See, e.g., Arizona v. Maricopa County Medical Soc'y, 102 S. Ct. 2466 (1982); United States v. Container Corp. of Am., 393 U.S. 333 (1969); Plymouth Dealers' Ass'n v. United States, 279 F.2d 128 (9th Cir. 1960).

92. See, e.g., National Soc'y of Professional Eng'rs v. United States, 435 U.S. 679 (1978); Goldfarb v. Virginia State Bar, 421 U.S. 773 (1975). In some cases the court claims to apply a per se rule but in fact applies a truncated rule of reason analysis. See Arizona v. Maricopa County Medical Soc'y, 102 S. Ct. 2466, 2477 (1982) ("LL]imited record in this case not inconsistent with the presumption that . . . agreements will not enhance competition."); United States v. Container Corp. of Am., 393 U.S. 333, 337 (1969) ("[T]he corrugated container industry is dominated by relatively few sellers.").

93. See Broadcast Music, Inc. v. Columbia Broadcasting Sys., Inc., 441 U.S. 1 (1979) (ASCAP).

94. Id. For discussion of ASCAP, see Louis, Restraints Ancillary to Joint Ventures and Licensing Agreements: Do Sealy and Topco Logically Survive Sylvania and Broadcast Music?, 66 VA. L. REV. 879, 897-99 (1980) (ASCAP places small, undefined area beyond reach of per se rule); Robinson, Recent Antitrust Developments-1979, 80 ColuM. L. REV. 1, 13-26 (1980) (ASCAP may signal revitalization of rule of reason for some price restraints). 
of musical compositions had formed associations to license performances of their works on a "blanket" basis. ${ }^{95}$ A broadcaster decided that the price of its blanket license was rising too fast and attempted to obtain per-use licenses from the musical associations. When the associations refused to grant per-use licenses, the broadcaster brought suit under section 1 of the Sherman Act. The Court held that the blanket licenses were not illegal per se even though the musical associations set one price for a blanket license and thus in some sense "fixed" a single price for individual compositions that might otherwise compete against one another. The Court noted that because the blanket license allows immediate and inexpensive use of covered compositions and greater flexibility in the use of musical material, ${ }^{96}$ it is in effect a different product from the separate compositions of individual composers. ${ }^{97}$ The music associations were thus not actually fixing the price of their individual compositions but setting a price for the new product-the blanket license. ${ }^{88}$

In Arizona v. Maricopa County Medical Society, ${ }^{99}$ the Court reached the opposite conclusion about a situation similar to ASCAP. In Maricopa, a group of physicians had formed "foundations" to set maximum fee schedules that members could charge to holders of an insurance plan. ${ }^{100}$ The insurers agreed to pay the full amount of their insureds' medical bills charged by participating physicians. ${ }^{101}$ The Court held that the physicians' setting of maximum fees to the insureds was illegal under the per se rule against price fixing. ${ }^{102}$

The court of appeals in Maricopa ${ }^{103}$ had held that the physicians' plan was not a per se violation but rather had to be evaluated in terms of purpose and effect. ${ }^{104}$ In deciding instead that the plan fell under the pro-

95. Broadcast Music, Inc. v. Columbia Broadcasting Sys., Inc., 441 U.S. 1, 5 (1979). The "blanket" license allowed the licensee to pay a flat fee and perform any composition owned by members of the associations as many times as desired. Id. Individual composer members were still free to negotiate separate licensing arrangements on their own. Id.

96. Id. at 20. Effective enforcement of a per-use license would require the licensor to monitor all performances of the licensee. The blanket license eliminated the need for such costly monitoring. Id.

97. Id.

98. "IT]o the extent the blanket license is a different product, ASCAP is not really a joint sales agency offering the individual goods of many sellers, but is a separate seller offering its blanket license, of which the individual compositions are raw material." Id. at 22 . The Court remanded the case for consideration of the legality of the blanket license under a rule of of reason. Id. at 25 .

99. 102 S. Ct. 2466 (1982). See generally Weller, Antitrust and Health Care: Provider Controlled Health Plans and the Maricopa Decision, 8 AM. J.L. \& MED. 223 (1982) (health care industry subject to same antitrust scrutiny applied to other industries); Note, Antitrust Foundations for Medical Care: Characterization of Maximum Fee Schedules, 1981 ARIZ. ST. L.J. 293 (Maricopa circuit court correct to refuse to characterize Maricopa plan as per se illegal).

100. $102 \mathrm{~S}$. Ct. at $2470-71$.

101. Id. at 2471 .

102. Id. at $2472-80$.

103. 643 F.2d 553 (9th Cir. 1980), rev'd, 102 S. Ct. 2466 (1982).

104. $102 \mathrm{~S}$. Ct. at 2469-70. 
scription of the per se rule, the Supreme Court speculated on possible anticompetitive effects of the plan without attempting to establish which, if any, of these effects would actually occur. The Court suggested that the plan might provide disincentives for more skillful physicians by rewarding all physicians equally, ${ }^{105}$ and that the plan might discourage experimentation, innovation, and entry into the market by competing physicians. ${ }^{108}$ The Court, however, did not consider the plausibility of such anticompetitive effects given that participation was voluntary for physicians and patients, that there were many physicians who would not be members of the plan, and that member physicians remained free to treat patients who were not plan members. ${ }^{107}$

The Court also maintained that there was no efficiency justification for the plan, since its benefits could be achieved by having the insurers set the maximum fees. ${ }^{108}$ In fact, however, the physicians could not allow the insurers to set maximum fees, since the physicians would have no way of offsetting fees they perceived as too low, for example, as a result of rising costs. But whatever fees the physicians set, the insurance companies would be able to adjust their premiums accordingly-and still charge a lower premium than if their liability were completely unlimited.

Furthermore, just as in ASCAP, the defendants in Maricopa were engaged in marketing a new product-low-cost, full-coverage health insurance. ${ }^{108}$ As in ASCAP, the new product was a "blanket" response to the high transaction costs of per-use purchases. ${ }^{110}$ In sum, there is no principled way to distinguish Maricopa from $A S C A P$. A rule so erratically applied can hardly be justified on the grounds that it provides enhanced predictability.

\section{Inconsistency}

The justification for the per se rule is further undermined by the inconsistency of the rule with certain well-established lines of decisions. Appli-

105. Id. at 2475 .

106. Id.

107. The arrangement allowed insureds to use the services of nonparticipating physicians (in which case coverage would extend only to the maximum amounts set under the plan), id. at 2472 , and also allowed participating physicians to charge whatever fees they chose to patients not covered by the plan, id. at 2471.

108. Id.

109. See Easterbrook, supra note 44 , at $898-900$.

110. Maximum fee schedules set by providers entail fewer transaction costs than those set by insurers, since under an insurer-determined fee schedule, each provider would have to make a separate decision to accept or reject each insurer's fee schedule, while under a provider-determined fee schedule each provider and each insurer would only have to make a single decision-whether or not to participate in the plan. Id. at 898. Easterbrook also points out that insurers have less information than suppliers about the relative costs of particular services, so that fee schedules set by insurers are less likely to clear the market. Id. 
cation of the per se rule in cases involving single-element price fixing ${ }^{111}$ is inconsistent with the courts' rule of reason approach to the similar or functionally equivalent arrangements involving standardization programs and exchanges of information.

Exchanges of information are subject to a rule of reason analysis in which the courts look at the purposes and effects of the arrangements and the market power of the parties. ${ }^{112}$ The courts recognize that the exchange of price information in competitive markets increases competition: In order for a seller to meet or undercut the prices of his competitors, he must know what those prices are; in order to set an efficient level of production, he must know how much customers are willing to pay. ${ }^{113}$ Likewise dissemination of price data may promote a competitive equilibrium in the market by making it easier for customers to compare prices. ${ }^{114}$ The illegality of informational activities must therefore depend on more than whether there was an agreement to exchange price information.

Standardization programs are also subject to a rule of reason treatment

111. Single-element price fixing is the fixing of some aspect of price, such as credit terms or delivery charges. See, e.g., Catalano Inc. v. Target Sales, Inc, 446 U.S. 643 (1980) (per curiam) (alleged agreement among beer distributors to eliminate short term credit to retailers); In re Plywood Antitrust Litig., 655 F.2d 627 (5th Cir. 1981) (alleged agreement to maintain delivered price system), cert. dismissed sub noms. Weyerhaeuser Co. v. Lyman Lamb Co. and Georgia-Pacific Corp. v. Lyman Lamb Co., 103 S. Ct. 3100 (1983).

112. See, e.g., United States v. United States Gypsum, 438 U.S. 422 (1978) (exchange of price information without intent to fix prices not criminal price fixing per se); United States v. Citizens \& S. Nat'l Bank, 422 U.S. 86, 113 (1975) ("IT]he dissemination of price information is not itself a per se violation of the Sherman Act."); Maple Flooring Mfrs. Ass'n v. United States, 268 U.S. 563 (1925) (mere dissemination of information not unreasonable restraint in absence of attempt to curtail production or raise prices); United States v. American Linseed Oil Co., 262 U.S. 371 (1923) (exchange of price and statistical information illegal where manifest purpose and necessary tendency of the entire arrangement was to suppress competition). In United States v. Container Corp. of Am., 393 U.S. 333 (1969), the Court struck down a price verification agreement, purportedly under the per se rule. At least one court later interpreted Container as standing for the rule that agreements among competitors to exchange price information with the purpose and effect of stabilizing the market are a per se violation, apparently ignoring the inconsistency involved in characterizing a per se rule in terms of "purpose and effect." United States v. F.M.C. Corp., 306 F. Supp. 1106, 1142 (E.D. Pa. 1969). The Container Court's analysis, however, is more consistent with a rule of reason. The Court stated that while "[p]rice information exchanged in some markets may have no effect on a truly competitive price ... the corrugated container industry is dominated by relatively few sellers . . . The product is fungible and the competition for sales is price. The demand is inelastic . . . " Container, 393 U.S. at 337. In any case, the Supreme Court later declared explicitly that dissemination of price information is not a per se violation. United States v. Citizens \& S. Nat'l Bank, 422 U.S. 86, 113 (citing concurring opinion in Container).

113. Dissemination of price information "tends to stabilize trade and industry, to produce fairer price levels and to avoid the waste which inevitably attends the unintelligent conduct of economic enterprise." Maple Flooring Mfrs. Ass'n v. United States, 268 U.S. 563, 593 (1925); cf. L. SULLIVAN, supra note 28, at 268 (price information exchanges promote competition in competitive markets but facilitate collusion in oligopolistic markets). But see Posner, supra note 79, at 1197-99 (exchanges of price information always narrow the dispersion of prices and should be legal per se, but may be used as evidence of conspiracy to fix prices).

114. Id. 
by the courts. ${ }^{116}$ With standardization competition may become more effective, as consumers can focus on prices, which can be readily compared, rather than on quality, which is difficult to compare. ${ }^{116}$ These possible procompetitive effects lead the courts to take a rule of reason approach to standardization.

There are circumstances under which price restraints have the same effects as quality restraints. The delivered pricing system in Plywood, for example, had the effect of facilitating price comparisons by buyers: ${ }^{117}$ Standardizing delivery charges while allowing total prices to fluctuate in response to competitive forces is the functional equivalent of product standardization. Since the courts have routinely taken a rule of reason approach to standardization programs on the ground that they facilitate price comparisons, consistency requires an equivalent treatment of cases involving the setting of a single element of price.

The holding in Plywood is similarly inconsistent with the established judicial approach to information exchanges. Because the Plywood system of delivered prices facilitated price comparisons, it had the same effect as a dissemination of price information among customers and should thus have been subject to the rule of reason applied to exchanges of price information. It is only the totemic significance attached to "price fixing" that has prevented a recognition of the structural similarity of these situations.

Furthermore, the per se rule is on its face inconsistent with the wellestablished rule of reason approach to exchanges of price information. As enunciated in Madison Oil, the per se rule specifically includes under its ban agreements "stabilizing" prices. ${ }^{118}$ One purpose of exchanges of price information, however, is precisely to lower the dispersion of prices so that producers can better adjust their pricing and output decisions to the conditions of the market. ${ }^{119}$ The blanket proscription of any "tamper[ing] with

115. See, e.g., Bond Crown \& Cork Co. v. FTC, 176 F.2d 974 (4th Cir. 1949) (standardization of bottle caps innocent in itself but not when combined with standardization of discounts and other agreements); Tag Mfrs. Inst. v. FTC, 174 F.2d 452 (1st Cir. 1949) (standardization of tags and exchange of price information upheld); Structural Laminates, Inc. v. Douglas Fir Plywood Ass'n, 261 F. Supp. 154 (D. Or. 1966) (refusal of association to certify particular type of plywood as meeting commerical standards not a restraint of trade), aff', 399 F.2d 155 (9th Cir. 1968), cert. denied, 393 U.S. 1024 (1969); Roofire Alarm Co. v. Underwriter's Laboratories, Inc., 188 F. Supp. 753 (E.D. Tenn. 1959) (testing corporation's standards as to warning devices not unreasonable), affd mem., 284 F.2d 360 (6th Cir. 1960). In National Macaroni Mfrs. Ass'n v. FTC, 65 F.T.C. 583 (1964), affd, 345 F.2d 421 (7th Cir. 1965), the Commission declared a standardization program illegal per se but in fact applied a truncated rule of reason analysis. See supra p. 716.

116. Furthermore, product differentiation may allow sellers to reap monopoly profits to the extent they can succeed in making their products appear unique. The theory is that if buyers perceive a product as qualitatively unique, they will be willing to pay more for it than they would have if it had perfect substitutes. See F. SCHERER, supra note 17, at 380-84. From this perspective too, then, product standardization may benefit consumers.

117. See supra pp. 718-19.

118. United States v. Socony-Vacuum Oil Co., 310 U.S. 150, 223 (1940) (Madison Oil).

119. According to Richard Posner, 
price structures"120 in Madison Oil cannot be reconciled with the rule of reason approach to information exchanges. This inconsistency is yet another source of uncertainty and unpredictability created by the per se rule.

\section{Efficiencies from "Price Fixing"}

The per se rule has also led courts to proscribe much efficiency-promoting activity. Possible productive efficiencies were proscribed in Maricopa, and possible informational efficiencies were ruled per se illegal in Plywood. Where the potential for such efficiencies exists, the courts should adopt a rule of reason approach that takes account of the purpose and effects of these arrangements and the market power of the parties involved. ${ }^{121}$

The courts have typically adopted such an approach in other areas where the potential for efficiency gains has been recognized. Thus, partnerships ${ }^{122}$ and joint ventures ${ }^{123}$ are generally evaluated using a rule of reason, even though both arrangements may involve some agreement as to price. A law partnership, for example, involves an agreement among the partners to set the fees they will charge for their services, but it also creates efficiencies from division of labor, specialization, and shared overhead. ${ }^{124}$ While partnerships may be used as a vehicle for collusive restraints, ${ }^{125}$ their potential for efficiency gains justifies the rule of reason

The purpose of a legitimate exchange of price information is to narrow the dispersion of prices-that is, to eliminate as far as possible those prices in the tails of the price distribution that reflect the ignorance of buyers or sellers concerning the conditions of supply and demand.

There is no reason to expect the price level-the average price in the market-to change.

Posner, supra note 79, at 1188 . This lesser dispersion also benefits consumers by lowering their search costs. Id. at 1195.

120. United States v. Socony Vacuum Oil Co., 310 U.S. 150, 221 (1940).

121. The use of the per se rule to proscribe possible efficiencies is particularly striking in some patent licensing cases. See United States v. Masonite Corp., 316 U.S. 265 (1942). The case is discussed in Priest, supra note 83, at 350-55 (fixing of licensee prices by licensor-patentee may deter crosion of royaliy, evoke presale services, or contribute to efficiency where costs fall unexpectedly after license is negotiated).

122. The legality of partnerships formed for legitimate purposes was established early in the history of the interpretation of the Sherman Act. See United States v. Joint Traffic Ass'n, 171 U.S. 505, 567-68 (1898) (contract of partnership not restraint of trade under reasonable construction of Sherman Act); United States v. Addyston Pipe \& Steel Co., 85 F. 271, 280 (6th Cir. 1898) (reduction in competition created by partnership legal since it is only ancillary to main purpose of agreement), modified and affd, 175 U.S. 211 (1899).

123. See, e.g., Berkey Photo, Inc. v. Eastman Kodak Co., 603 F.2d 263, 302 (2d Cir. 1979) (lawfulness of joint venture to be evaluated in terms of size and market share of participants, contribution of each party, likelihood that each participant would undertake similar project in absence of joint venture, nature of ancillary restraints imposed, and reasonableness of restraints in relation to purpose of venture), cert. denied, 444 U.S. 1093 (1980); United States v. Penn-Olin Chem. Co., 378 U.S. 158 (1964) (test of legality of joint ventures under Clayton Act is whether joint venture is likely to injure competition); see also Brodley, Joint Ventures and Antitrust Policy, 95 HaRV. L. REV. 1521, 1535 (1982) (joint ventures evaluated under rule of reason in absence of flagrant cartel practices).

124. See $\mathrm{R}$. BORK, supra note 2 , at 265-66.

125. See United States v. Timken Roller Bearing Co., 83 F. Supp. 284, 312 (N.D. Ohio 1949) 
that courts apply to them. Similarly, joint ventures may create efficiencies in the form of new productive capacity, new technology, or a new product or entry into a new market, ${ }^{128}$ and it is therefore appropriate that they too be analyzed under the rule of reason.

The ill-defined notion of price fixing used by the courts in applying the per se rule has led to the proscription of activities that can plausibly be characterized as joint ventures and that therefore deserve consideration under a rule of reason. In United States v. Nationwide Trailer Rental System, Inc., ${ }^{127}$ for example, a group of independent owners set up the defendant corporation to facilitate establishment of a one-way trailer rental business. ${ }^{128}$ The corporation allowed its members to rent trailers on a one-way basis to destinations at which there was another member station; ${ }^{128}$ the owners of the trailers (each of whom operated at least one station) and the operators of the stations to which they were sent split the rental fees. ${ }^{130}$ The defendant circulated suggested fee schedules ${ }^{131}$ as well as a form lease containing a fixed rate for overtime. ${ }^{132}$ The district court found this conduct to be "price fixing" and declared it "illegal per se" under the Sherman Act. ${ }^{138}$

The court thereby overlooked the efficiencies that may be created by a centralized dissemination of price information. First, the scheme made possible an enormous savings in transaction costs. The corporation's members owned over 10,000 trailers, each of which made an average of fifteen moves per year. ${ }^{134}$ The costs of bilateral negotiations to determine rental fees for each of these 150,000 transactions would have been considerable. Second, the fee schedule facilitated more accurate pricing. While an independent trailer owner in Maine, for example, would have difficulty knowing what price to charge for a rental from Denver to San Francisco, the central headquarters of the corporation could more cheaply monitor supply and demand across the country and suggest the most competitive rental prices.

(partnership illegal when formed for purpose of allocating exclusive sales territories, fixing prices, and eliminating competition), modified and aff', 341 U.S. 593 (1951).

126. See Brodley, supra note 123 , at 1526 . Joint ventures and partnerships by no means exhaust the variety of joint economic activities that may create new products or efficiency gains and that have therefore been analyzed under a rule of reason. See Los Angeles Memorial Coliseum Comm'n v. NFL, 634 F.2d 1197 (1980) (antitrust suit against NFL, an unincorporated association, for rule requiring three-fourths vote of team owners before league member could transfer location of home games).

127. 156 F. Supp. 800 (D. Kan.), aff'd mem., 355 U.S. 10 (1957).

128. Id. at 802 .

129. Id. at 801 .

130. Id. at 804 .

131. Id.

132. Id.

133. Id. at 805.

134. Id. 
The efficiencies that may be created by such "price fixing" agreements as those in Nationwide Trailer and Maricopa are similar to those available from joint ventures: In both cases, cooperative efforts provide a product or service that might otherwise not be available to consumers. Because a per se rule automatically strikes down such cooperative activities if they can be labeled "price fixing," the per se rule should be replaced by a rule of reason for price restraints, which would allow the potential for efficiency gains to be taken into account in deciding the legality of such arrangements. ${ }^{195}$

\section{Dispensing with the Per Se Rule}

Although one commentator has argued that the invidious effects of the per se rule can be avoided if the rule is properly interpreted, this attempt to save the per se rule is internally inconsistent.

\section{A. Bork's Analysis of the Per Se Rule}

Robert Bork has argued that the exceptions to the per se rule for legitimate commercial arrangements such as partnerships do not detract from the rule's merit, ${ }^{136}$ since these exceptions can be given a principled basis by means of the distinction between primary and ancillary restraints. ${ }^{137}$ According to Bork, if a price restraint accompanies a "contract integration"138 or contributes to the efficiency of such an integration, it is ancillary and should be tested by the rule of reason. ${ }^{139}$ If a price restraint is not ancillary, it is "naked" and should be struck down by the per se rule. ${ }^{140}$

The chief difficulty with this approach is that it merely pushes analysis

135. Although the concern here is solely with horizontal restraints, the courts have also insisted upon a per se approach in numerous cases involving the vertical practice of resale price maintenance. They have done so despite recent scholarship indicating that resale price maintenance may be necessary to avoid the "free rider" problem in connection with enhanced point-of-sale services. See $\mathbf{R}$. BORK, supra note 2, at 280-98; R. POSNER, supra note 32, at 147-66; Bork, The Rule of Reason and the Per Se Concept: Price Fixing and Market Division II, 75 YALE L.J. 373, 429-64 (1966).

136. R. BORK, supra note 2 , at 267. According to Bork, Madison Oil is one of the "great cases" establishing the per se rule. Id. at 263.

137. Id. at 267. Bork traces his notion of ancillary restraints back to Judge Taft's opinion in United States v. Addyston Pipe \& Steel Co., 85 F. 271, 280-83 (6th Cir. 1898) (agreement of partners not to compete with partnership one of the ancillary restraints legal at common law and by implication under Sherman Act), modified and afPd, 175 U.S. 211 (1899).

138. The term "contract integration," as used by Bork, appears to include any cooperative productive activity not organized as a corporation. R. BORK, supra note 2 , at 264 . Thus, just as horizontal mergers between corporations may create efficiencies by integrating productive activities, so too may contract integrations such as partnerships or joint ventures. Id. For the economic basis of the distinction between contract integration and organization as a firm, see Coase, The Nature of the Firm, 4 ECONOMICA (n.s.) 386 (1937).

139. R. BORK, supra note 2 , at 264 .

140. Id. 
back to the question of when a restraint is ancillary, a question that must be addressed in terms of the power-purpose-effects analysis of the rule of reason. ${ }^{141}$ Thus, in the example Bork gives, the agreement among the members of a law partnership to set the fees for their services is an ancillary restraint because it is incidental to the main purpose of providing legal services more efficiently. ${ }^{\mathbf{1 4 2}}$ To determine whether a restraint is ancillary it is thus necessary to know its purpose, but an investigation of purpose is an element of a rule of reason analysis, not of a per se rule. Furthermore, in order to know the purpose of an agreement, it is often necessary to examine its probable effects, ${ }^{148}$ another inquiry characteristic of a rule of reason. Thus, Bork's approach is really a truncated rule of reason analysis and is inconsistent with the per se rule he wishes to retain. ${ }^{144}$ Furthermore, by permitting the courts to retain the per se rule in the judicial arsenal, Bork's approach would still allow the arbitrary labeling that has been the chief disadvantage of the per se rule. ${ }^{145}$ Bork's formulation of the per se rule would also incur the costs of overinclusiveness associated with deciding disputes using blanket categories, rather than on a case-by-case basis. For example, Bork's approach would continue to proscribe informational efficiencies, such as those in Plywood, that are not associated with any contract integration. ${ }^{146}$ Completely dispensing with the per se rule would bring greater consistency to the case law and promote many more efficient but currently proscribed activities than would be allowed under Bork's approach.

141. See supra note 7 .

142. Bork elaborates upon Judge Taft's analysis in Addyston Pipe \& Steel: "Taft argued that the elimination of competition inherent in the joining of men as partners was justified because this effect was only an incident to the main purpose of a union of their capital, enterprise, and energy to carry on a successful business, and one useful to the Community." R. BORK, supra note 2, at 264 (quoting United States v. Addyston Pipe \& Steel Co., 85 F. 271, 280 (6th Cir. 1898), modified and affd, 175 U.S. 211 (1899)).

143. Bork infers a benign purpose for a law partnership because "[n]obody supposes that a law firm in New York fixes its fees . . . for the purpose of restricting output. Each firm faces the rivalry of scores or hundreds of other firms, so that output restriction is not a tenable hypothesis." Id. at 265. The finding of ancillarity here involves a determination of the market power of the partners and the probable effects of their agreement.

144. "None of this [primary/ancillary] analysis in any way detracts from the merit of the per se rule." Id. at 267.

145. Under Bork's approach, the unprincipled leeway that the courts currently have in either applying a conclusory label of price fixing or engaging in a tacit rule of reason analysis would be duplicated in the determination of the restraint's ancillarity.

146. Nor would the primary-ancillary distinction reconcile the per se approach of the single clement price fixing cases with the well-established use of the rule of reason for evaluating standardization programs and exchanges of price information. See supra pp. 723-25. 


\section{B. The Continued Proscription of Cartels}

The chief difficulty with the per se price fixing rule is that the courts have developed no coherent theory of what constitutes price fixing. There is, however, a well-established theory showing that cartelization-as distinguished from price fixing-usually creates efficiency losses. ${ }^{147}$

Cartel behavior would, therefore, still be struck down under a rule of reason approach to price fixing. The judicial inquiry would in fact be the same as that under the per se approach of the early cases: Once the existence of a cartel with market power had been established, a holding of illegality would follow automatically, since the net economic consequences of a cartel are almost certainly invidious. Thus, there would continue to be an irrebutable presumption against cartels, but this presumption would not come into play until after a rule of reason analysis involving market power, purpose, and probable effects established the existence of a dangerous cartel. ${ }^{1+8}$ This approach would allow much of the savings in administrative costs provided by a per se rule to be preserved while avoiding the invidious effects of the rule as it is currently applied. ${ }^{148}$

147. See supra p. 711. Under some rare circumstances, cartels may promote efficiency. For example, a cartel could be used to insure enhanced point-of-sale services by eliminating the "free rider" problem. If the sellers of a product agree upon a supracompetitive price, they will have an incentive to compete by making increased information and services available to customers, since they will not be undercut by competitors who provide no information or services. Theoretically, the increased services could raise the marginal costs of the cartel members to the selling price of the product, so that there would be no supracompetitive profits. See R. BORK, supra note 2, at 435 . Free rider problems that could be remedied only by a cartel, however, are probably rare. See $\mathbf{R}$. POSNER, supra note 32 , at 22 ("few economists believe collusive pricing generates significant economic gains").

148. For an innovative analysis of the determinants of market power, see Landes \& Posner, supra note 31. According to Landes and Posner, the "Lerner index" is the appropriate measure of a firm's (or group of firms') market power. Id. at 939-40. Because the Lerner index may be derived from an equation relating a firm's (or group of firms) market share, the market elasticity of demand, and the elasticity of supply of competing producers, id. at 945, an important claim of the Landes-Posner analysis is that efficiency losses from any given degree of market power can actually be measured. Id. at $953-55$.

Although the Landes-Posner model provides a theoretical basis for a rule of reason approach to price fixing, its application to judicial decisionmaking would have to recognize the gap that exists between the ideal models of price theory and the real world of markets. Most importantly, competitive markets in the real world may not display prices equal to the marginal costs of each producer. Sellers may have different costs, and since the competitive price is equal to the marginal cost of the highestcost producer, it will be above the marginal costs of the other producers. Second, unanticipated upward shifts in demand will raise competitive prices above marginal costs as a short-term mechanism for rationing the available supply. See R. POSNER, supra note 32, at 136-37. In general, whenever demand exceeds supply (as it often may in the real world), prices will be above marginal costs. Under these circumstances, a per se rule against cartels should not proscribe all agreements that maintain prices above marginal costs but only those that maintain a difference between price and marginal cost greater than would exist in the absence of the agreement.

149. Implementation of a rule of reason approach to price fixing could occur either tacitly or explicitly. In the tacit approach, the courts would refrain from engaging in the conclusory labeling that has often characterized the per se method. Price fixing agreements would continue to be struck down if analysis based on the economic structure of the situation revealed invidious purposes or effects, actual or prospective. In the explicit approach, the Supreme Court would simply overrule Madison Oil or limit its holding to cartel behavior. The tacit approach would still allow scope for 


\section{Conclusion}

The supposed advantages of the per se approach to price fixing no longer hold up under scrutiny. There is no coherent economic rationale behind the per se approach, and the erratic and inconsistent application of the doctrine has not resulted in greater reliability or predictability. There is some merit to the argument that a per se rule provides greater ease of judicial administration, but it does so precisely because it arbitrarily proscribes all agreements touching upon price, regardless of their economic consequences. ${ }^{150}$ Furthermore, to the extent that a per se approach emphasizes proof of price fixing conspiracies instead of anticompetitive purposes or effects, the savings in administrative costs that the rule provides are significantly reduced by the expensive and extended discovery typical of conspiracy cases.

A rule of reason approach to price fixing would make judicial analysis more consistent with economic theory. By expressly recognizing that the efficiency effects of every price restraint must be evaluated in determining its legality, it would eliminate the erratic labeling made possible by the absence of a coherent economic definition of price fixing. A rule of reason would also make the courts' approach to arrangements such as single element price fixing more consistent with their treatment of information exchanges and standardization programs. All of these activities may create efficiencies by reducing information costs in the market, and all deserve a rule of reason analysis. Finally, a rule of reason will in general promote more wealth gains than a per se rule because it recognizes the unpredictable variety of arrangements that may create efficiencies, even though they involve some agreement as to price.

inconsistency, since it would signal no clear departure from the courts' current practice of selectively peeking at the economic merits while ostensibly applying a per se rule. Accordingly, the explicit approach is more desirable.

150. Warren Schwartz has made a related point with respect to prosecutorial discretion and assessment of damages:

One supposed advantage of per se rules is to increase certainty and reduce process costs by determining liability through simple descriptive criteria. As a result of this simplification, however, cases falling within the generalized prohibition vary with respect to the amount of harm they cause. If these variations are disregarded by the prosecutor in the exercise of prosecutorial discretion, or the judge or jury in fixing a penalty or assessing damages, both the intensity of enforcement and the magnitude of the sanction will be determined inappropriately. If these variations are taken into account, however, the claimed savings in process costs from a per se rule seems to be overstated.

Schwartz, An Overview of the Economics of Antitrust Enforcement, 68 GEO. L.J. 1075, 1089 (1980). 